Francis F. Foldes MD, Hideo Nagashima MD, Hung D. Nguyen MD, Deryck Duncalf MD, Paul L. Goldiner MD

\title{
Neuromuscular and cardiovascular effects of pipecuronium
}

Pipecuronium bromide (Arduan) is a bisquaternary, steroidtype neuromuscular blocking agent in clinical use in Eastern Europe. Before its introduction into clinical practice in the USA, in the first phase of this study the neuromuscular potency of pipecuronium was determined under "balanced" and enflurane anaesthesia by the cumulative log dose-response method in 30 patients each. In the second phase the intubation and onset times, clinical duration of the first and repeated doses, spontaneous recovery index, reversibility of its residual neuromuscular effect by an anticholinesterase and its effect on heart rate and blood pressure was compared with the same variables observed in patients, anaesthetized with identical techniques but who had received vecuronium or pancuronium. The neuromuscular potency of pipecuronium was greater under enflurane $\left[E D_{95}=23.6 \pm I . I \mu \mathrm{g} \cdot \mathrm{kg}^{-1}\right.$ (mean $\left.\left.\pm S E M\right)\right]$ than under balanced $\left(E D_{95}=35.1 \pm 17 \mu \mathrm{g} \cdot \mathrm{kg}^{-1}\right)$ anaesthesia. Pipecuronium was more potent than vecuronium under both balanced $\left(E D_{95}=45.8 \mu \mathrm{g} \cdot \mathrm{kg}^{-1}\right)$ and enflurane anaesthesia $\left(E D_{95}=\right.$ $\left.27.4 \mu \mathrm{g} \cdot \mathrm{kg}^{-1}\right)$. Following the administration of $2 \times E D_{95}$ doses there were no clinically significant differences in the intubation or onset times of pipecuronium, vecuronium and pancuronium. Under balanced anaesthesia the clinical duration of $2 \times E D_{95}$ dose of pipecuronium (110.5 $\pm 0.3 \mathrm{~min}$ ) or pancuronium ( 115.8 $\pm 8.1 \mathrm{~min}$ ) were similar and about three times longer than that of vecuronium $(36.3 \pm 2.1 \mathrm{~min})$. The recovery indices of pipecuronium (44.5 $\pm 8.2 \mathrm{~min}$ ) and pancuronium (41.3 \pm 4.2 min) were also similar and about three times longer than that of vecuronium (14.3 \pm 1.4 min). Residual neuromuscular block of the three muscle relaxants could be equally well reversed by anticholinesterases at the end of anaesthesia. The $2 \times E D_{95}$ doses of pipecuronium or vecuronium had no significant effect

\section{Key words}

COMPLICATIONS: cardiovascular;

NEUROMUSCULAR RELAXANTS: pancuronium, pipecuronium, vecuronium.

From the Department of Anesthesiology, Montefiore Mcdical Center, Albert Einstein College of Medicine, Bronx, NY 10467.

Address correspondence to: Dr. F. F. Foldes, Department of Anesthesiology, Montefiore Medical Center, 111 East 210th Street, Bronx, NY 10467. on heart rate or blood pressure. Pancuronium increased heart rate by about 20 per cent. Pipecuronium is preferable to pancuronium for the production of muscular relaxation for relatively long operations, when it is desirable to avoid acceleration of heart rate.

Le bromure de pipécuronium (Arduan) est un curare biquaternaire de type stéroïdien employé en Europe de l'Est. Nous avons mesuré quelques unes de ses propriétés avant d'en recommander l'usage clinique aux Etats-Unis. Dans un premier temps, nous avons déterminé sa puissance en comparant la réponse neuromusculaire au logarythme de la dose cumulative chez deux groupes de 30 patients. Nous avons établi que sa $D E_{95}$ était de $23,6 \pm 1,1 \mu \mathrm{g} \cdot \mathrm{kg}^{-1}$ (moyenne \pm erreur-type) sous anesthésie à l'enflurane, et de $35,1 \pm 17 \mu \mathrm{g} \cdot \mathrm{kg}^{-1}$ sous neurolepanesthésie tandis que ces deux valeurs étaient respectivement de: 27,4 $\mu \mathrm{g} \cdot \mathrm{kg}^{-1}$ et $45,8 \mu \mathrm{g} \cdot \mathrm{kg}^{-1}$ pour le vécuronium. Dans un deuxième temps, nous avons établi qu'en présence de conditions anesthésiques identiques, l' injection d' une dose égale $2 \times D E_{95}$ s'accompagnait de temps de latence avant le début d'action et l'instauration de conditions propices à l'intubation virtuellement semblables pour le pipécuronium, le pancuronium et le vécuronium tandis que sa durée d'action s'établissait dans l'ordre à $110,5 \pm 0,3 \mathrm{~min}, 115,8 \pm 8,1$ min et $36,3 \pm 2,1$ min et son index de récupération d̀ 44,5 $\pm 8,2 \mathrm{~min}, 41,3 \pm 4,2$ min et $14,3 \pm 1,4$ min pour ces mémes produits. A la fin de l'intervention, le bloc neuromusculaire résiduel était aussi facile à contrer avec un inhibiteur de la cholinestérase quelque soit le myorelaxant employé. Le pipécuronium et le vécuronium à raison d'une dose égale à $2 \times D E_{95}$ ne modifièrent ni la pression artérielle ni la fréquence cardiaque tandis que cette dernière augmentait de 20 pour cent avec le pancuronium. II semble donc que si on veut utiliser un myorelaxant de longue durée sans accélérer le pouls, on doive préférer le pipécuronium au pancuronium.

Pipecuronium bromide (Arduan) is a steroid base, bisquaternary neuromuscular blocking agent (muscle relaxant) (Figure 1). It has been used in Eastern Europe for the production of muscular relaxation during surgery. ${ }^{1-4}$ In these studies the potency, speed of onset, and duration of the neuromuscular effect of pipecuronium was found to be similar to those of pancuronium. Unlike pancuronium, 
CMEMICAL STRUCTURE
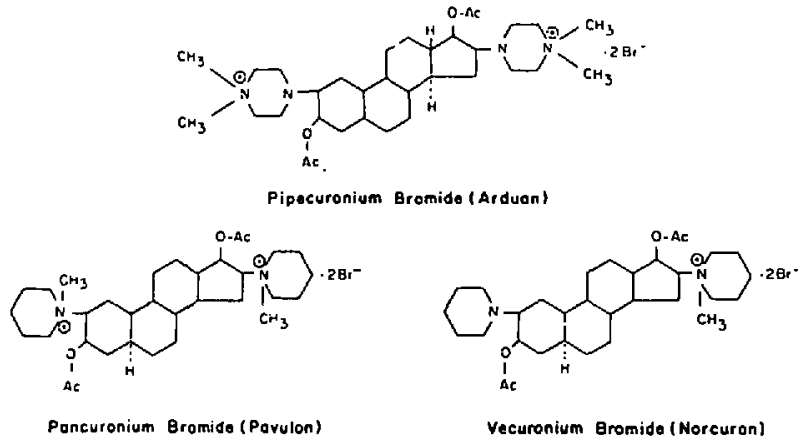

FIGURE 1 Structural formulae of pipecuronium, pancuronium and vecuronium.

however, it had no unwanted circulatory side effects. This paper summarizes the observations made on the comparative neuromuscular and cardiovascular effects of pipecuronium and vecuronium bromide in a two-phase study. In the first phase, referred to as "dose-response study" the neuromuscular potency of pipecuronium and vecuronium were determined in patients under balanced or enflurane anaesthesia. In the second phase, referred to as "clinical study" the neuromuscular and cardiovascular effects of the $2 \times \mathrm{ED}_{95}$ doses of pipecuronium and vecuronium were observed in patients under balanced anaesthesia.

\section{Methods}

The studies reported in this paper were approved by our Institutional Review Board. Male and female, ASA physical status I, II or III patients of 18 to 65 years of age signed informed consents. Females with child bearing potential and patients who had pathological conditions (e.g., myasthenia gravis, myotonias) or received drugs, other than those used for anaesthetic management, which could have affected the neuromuscular and cardiovascular parameters studied were excluded.

\section{Anaesthetic management}

All patients were given IM 50 to $100 \mathrm{mg}$ diphenhydramine hydrochloride and 50 to $100 \mathrm{mg}$ meperidine hydrochloride 60 to $90 \mathrm{~min}$ before induction of anaesthesia. Two types of anaesthetic techniques were employed. The first, to be referred to as "balanced anaesthesia," consisted of induction with 0.5 to $1 \mu \mathrm{g} \cdot \mathrm{kg}^{-1}$ fentanyl, $0.10 \mathrm{mg}$. $\mathrm{kg}^{-1}$ droperidol and 2 to $3 \mathrm{mg} \cdot \mathrm{kg}^{-1}$ thiopentone sodium all injected $\mathrm{IV}$ and $4 \mathrm{~L} \cdot \min ^{-1} \mathrm{~N}_{2} \mathrm{O}-2 \mathrm{~L} \cdot \min ^{-1} \mathrm{O}_{2}$. After induction of anaesthesia an oropharyngeal airway was inserted and the patients' ventilation was manually assisted or controlled, with the help of a face mask, until intuba- tion. Anaesthesia was maintained with a $2 \mathrm{~L} \mathrm{~N}_{2} \mathrm{O}-1 \mathrm{~L} \mathrm{O}_{2}$ gas mixture, 25-100 $\mu \mathrm{g}$ increments of fentanyl and occasionally with $25-100 \mathrm{mg}$ thiopentone. With the second anaesthetic technique, to be referred to as "enflurane anaesthesia," premedication was the same as in the balanced anaesthesia group. Anaesthesia was induced with $3-5 \mathrm{mg} \cdot \mathrm{kg}^{-1}$ thiopentone and $3 \mathrm{~L} \cdot \mathrm{min}^{-1} \mathrm{~N}_{2} \mathrm{O}-2 \mathrm{~L}$. $\min ^{-1} \mathrm{O}_{2}$ containing three per cent inspired concentration of enflurane for five minutes and two per cent thereafter for five more minutes. Anaesthesia was maintained with $0.5-1.5$ per cent inspired concentration of enflurane, as indicated, in $2 \mathrm{~L} \cdot \mathrm{min}^{-1} \mathrm{~N}_{2} \mathrm{O}-1 \mathrm{~L} \cdot \mathrm{min}^{-1} \mathrm{O}_{2}$. Endexpiratory $\mathrm{PCO}_{2}$ was kept at $35 \pm 3 \mathrm{mmHg}$ during both the dose-response and clinical studies.

\section{Monitoring of neuromuscular transmission}

Neuromuscular transmission was monitored in both the dose-response and clinical studies by continuous recording of the force of contraction of the adductor pollicis muscle, elicited by indirect stimulation of the ulnar nerve at the wrist, and quantitated by FT 10 transducers. Single supramaximal, square wave impulses of $0.2 \mathrm{~ms}$ duration were administered every ten seconds in the vecuronium dose-response studies. Trains-of-four (TOF) similar impulses were administered at $2 \mathrm{~Hz}$ every ten seconds in the pipecuronium dose-response and in all the clinical studies.

\section{Determination of the dose-response}

The cumulative dose method was used for the determination of the dose-response of the long-acting pipecuronium and the individual dose method was employed for that of the "medium"-acting vecuronium. The cumulative dose-response of pipecuronium was determined in 30 patients each under balanced or enflurane anaesthesia. The initial dose of pipecuronium was $15 \mu \mathrm{g} \cdot \mathrm{kg}^{-1}$ under balanced and $12 \mu \mathrm{g} \cdot \mathrm{kg}^{-1}$ under enflurane anaesthesia. Depending on the effect of the first dose the second dose of pipecuronium was 5 or $10 \mu \mathrm{g} \cdot \mathrm{kg}^{-1}$ in both groups. Subsequent increments of $5 \mu \mathrm{g} \cdot \mathrm{kg}^{-1}$ were given in both groups until 85 to 95 per cent neuromuscular block developed. Subsequently neuromuscular block was completed with an additional $5-10 \mu \mathrm{g} \cdot \mathrm{kg}^{-1}$, increment of pipecuronium and the tracheas were intubated.

The dose-response of vecuronium was determined with the individual dose method. Groups of five, six and seven subjects received 26,32 or $38 \mu \mathrm{g} \cdot \mathrm{kg}^{-1}$ vecuronium, respectively, in the balanced anaesthesia group. Under enflurane anaesthesia five subjects each received 19, 22 or $25 \mu \mathrm{g} \cdot \mathrm{kg}^{-1}$ vecuronium. After development of the maximal effect of the selected dose neuromuscular block was completed with $60-80 \mu \mathrm{g} \cdot \mathrm{kg}^{-1}$ vecuronium and the tracheas were intubated. 


\section{Clinical studies}

In the clinical studies patients were given IV a single dose of $80 \mu \mathrm{g} \cdot \mathrm{kg}^{-1}$ pipecuronium, or $100 \mu \mathrm{g} \cdot \mathrm{kg}^{-1}$ vecuronium or pancuronium. Ventilation was assisted or controlled until the force of contraction of the thumb decreased to 20-25 per cent of control. At this time the tracheas were intubated. The maximal neuromuscular effect and the time from the start of injection of the muscle relaxant to the development of its maximal effect (onset time) and the time required for the return of the twitch tension to 25 per cent of control after injection of the initial dose (clinical duration) were recorded.

Patients, in both the dose-response and clinical studies, requiring muscular relaxation beyond the clinical duration of the intubating dose were given $15 \mu \mathrm{g} \cdot \mathrm{kg}^{-1}$ incremental doses of one of the three muscle relaxants under balanced and $12 \mu \mathrm{g} \cdot \mathrm{kg}^{-1}$ under enflurane anaesthesia. Each patient received only one type of relaxant.

Recovery of neuromuscular transmission was allowed to proceed spontaneously for as long as possible without seriously delaying the operating room schedule. In most patients, however, the residual neuromuscular block was antagonized either with a mixture of $40 \mu \mathrm{g} \cdot \mathrm{kg}^{-1}$ neostigmine and $15 \mu \mathrm{g} \cdot \mathrm{kg}^{-1}$ atropine in the pipecuronium or that of $0.5 \mathrm{mg} \cdot \mathrm{kg}^{-1}$ edrophonium and 10 $\mu \mathrm{g} \cdot \mathrm{kg}^{-1}$ atropine in the vecuronium and pancuronium groups. The antagonists were injected over $60 \mathrm{sec}$. The $T_{1}$ (the force of contraction elicited by the first of TOF impulses expressed as per cent of control) and the $T_{4} / T_{1}$ ratio was measured before and at $2,5,8$ and $10 \mathrm{~min}$ after the administration of the antagonists.

Heart rate (monitored by ECG) and systolic and diastolic blood pressures (measured with Dinamap, Vital Signs Monitor \#1846 SX, Criticare, Inc.), were recorded before induction of anaesthesia, before the administration of $2 \times \mathrm{ED}_{95}$ dose of the muscle relaxant, before tracheal intubation, before and at 2, 5, 8 and $10 \mathrm{~min}$ after the administration of the antagonist and otherwise at tenminute intervals throughout anaesthesia.
Statistics

The statistical significance of the differences of the various parameters were determined with ANOVA followed by Tukey's ${ }^{5}$ test or by paired $t$ test as indicated, $P$ $<0.05$ was considered significant.

\section{Results}

The demographic data of the patients who participated in our dose-response and clinical studies are summarized in Table I.

\section{Dose-response studies}

Pipecuronium on a weight basis is more potent than vecuronium in patients under both balanced and enflurane anaesthesia and both muscle relaxants are more potent with enflurane than with balanced anaesthesia (Table II). The dose-response regression lines of vecuronium under balanced and enflurane anaesthesia are close to parallel (Figure 2).

Since the doses of pipecuronium and vecuronium used before intubation were administered in several increments the clinical duration of the "first" dose could not be determined in the dose-response studeos. The clinical duration of repeat doses (the time interval between the administration of a repeat dose and the return of $T_{1}$ to 25 per cent of control), the recovery index (time for the return of $T_{1}$ from 25 to 75 per cent of control) and the effect of anticholinesterases on the residual neuromuscular block, however, could be determined in these studies. After the retum of neuromuscular transmission to 25 per cent of control following the initial doses of the two muscle relaxants there was no difference in the administration of incremental doses of pipecuronium or vecuronium or of antagonists in the dose-response or clinical studies. Thus, the clinical duration and recovery data obtained in the dose-response studies will be considered together with those obtained in the clinical studies.

\section{Clinical studies}

The neuromuscular variables determined after the single

TABLE I Demographic data of patient populations

\begin{tabular}{|c|c|c|c|c|c|c|c|}
\hline \multirow[b]{2}{*}{ Study } & \multirow{2}{*}{$\begin{array}{l}\text { Type of } \\
\text { anaesthesia }\end{array}$} & \multirow{2}{*}{$\begin{array}{l}\text { Muscle } \\
\text { relaxant }\end{array}$} & \multirow{2}{*}{$\begin{array}{l}\text { Number of } \\
\text { patients }\end{array}$} & \multirow[b]{2}{*}{ Age } & \multirow{2}{*}{$\begin{array}{l}\text { Weight } \\
(\mathrm{kg})\end{array}$} & \multicolumn{2}{|c|}{ Sex } \\
\hline & & & & & & $M$ & $F$ \\
\hline \multirow[t]{4}{*}{ Dose - response } & Balanced & Pipecuronium & 30 & $49.3 \pm 2.5^{*}$ & $71.6 \pm 6.1$ & 17 & 13 \\
\hline & & Vecuronium & 18 & $44.9 \pm 2.9$ & $73.2 \pm 3.6$ & 8 & 10 \\
\hline & Enflurane & Pipecuronium & 30 & $46.6 \pm 2.3$ & $73.2 \pm 1.4$ & 16 & 14 \\
\hline & & Vecuronium & 15 & $36.6 \pm 3.5$ & $73.8 \pm 3.2$ & 8 & 7 \\
\hline \multirow[t]{3}{*}{ Clinical } & Balanced & Pipecuronium & 22 & $49.9 \pm 2.8$ & $76.4 \pm 1.6$ & 18 & 4 \\
\hline & & Vecuronium & 10 & $43.3 \pm 3.7$ & $73.8 \pm 2.4$ & 4 & 6 \\
\hline & & Pancuronium & 10 & $37.3 \pm 4.1$ & $76.9 \pm 6.2$ & 4 & 9 \\
\hline
\end{tabular}

*Mean \pm SEM. 


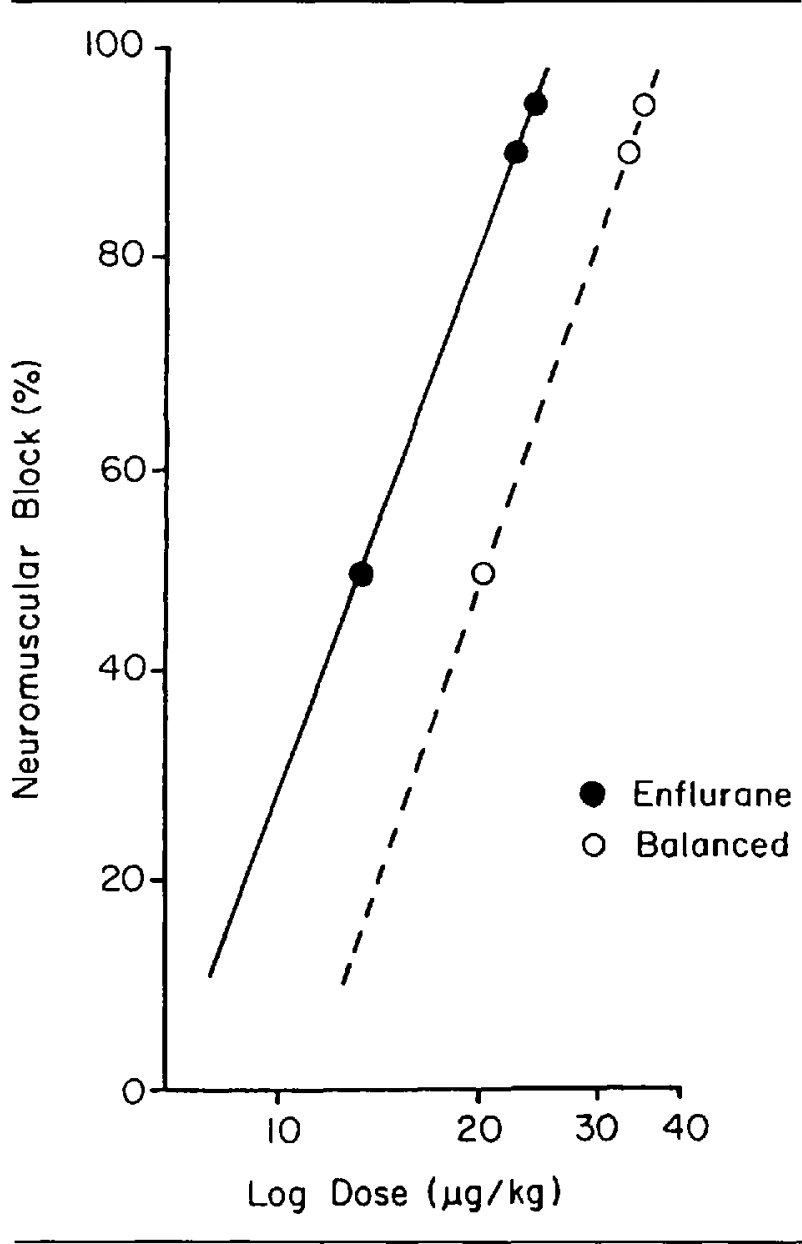

FIGURE 2 The log dose-response regression line of the neuromuscular effect of pipecuronium under balanced and enflurane anaesthcsia.

intravenous injection of $2 \times \mathrm{ED}_{95}$ doses of the three muscle relaxants are summarized in Table III. The onset time of pipecuronium and pancuronium were very similar and both were shorter $(P<0.05)$ than that of vecuronium. The intubation time of pipecuronium was shorter $(P<$ 0.05 ) than that of vecuronium, but the difference was clinically unimportant. In contrast the clinical duration of the intubating dose of vecuronium was about one-third of those of pipecuronium or pancuronium $(P<0.001)$. Similarly, in the few cases in which it was possible to observe this variable, the recovery rate of vecuronium was also about one-third of that of pipecuronium $(P<$ 0.001 ).

The clinical duration of the first maintenance doses of vecuronium were also about one-third of those of pipecuronium or pancuronium $(P<0.001)$ (Table IV). Under balanced anaesthesia the clinical duration of the first 15 $\mu \mathrm{g} \cdot \mathrm{kg}^{-1}$ repeat dose of vecuronium is also about onethird of the same dose of vecuronium or pancuronium (Table IV). There is a similar relationship in the clinical duration of the first repeat dose of $12 \mu \mathrm{g} \cdot \mathrm{kg}^{-1}$ repeat dose of vecuronium and pipecuronium. The number of second and third repeat doses of pipecuronium was too small for valid statistical analysis of their clinical duration. For the same reason it could not be determined whether or not pipecuronium has any cumulative effect.

The residual neuromuscular effect of the three muscle relaxants could be readily antagonized by anticholinesterases. After balanced anaesthesia (Table V) when the residual pipecuronium block was reversed with neostigmine-atropine, the mean $T_{4} / T_{1}$ ratio was 0.75 at 8 min and 0.79 at $10 \mathrm{~min}$. When vecuronium or pancuronium was reversed with edrophonium-atropine the mean $\mathrm{T}_{4} \mathrm{~T}_{1}$ ratio was 0.86 and 0.78 , respectively, at $2 \mathrm{~min}$. After enflurane anaesthesia, when the residual pipecuronium block was reversed by neostigmine-atropine the $\mathrm{T}_{4} / \mathrm{T}_{1}$ ratio was 0.80 at $5 \mathrm{~min}$ (Table VI). Interestingly, in this group, after the administration of the antagonist, the $T_{4} / T_{1}$ ratio returned towards control more rapidly than $T_{1}$. After antagonism of the residual vecuronium block with edrophonium-atropine the mean $T_{4} / T_{1}$ ratio was 0.86 at $2 \mathrm{~min}$.

The influence of the three muscle relaxants on heart rate and systolic and diastolic blood pressure, summarized in Table VII, indicate that pipecuronium and vecuronium

TABLE II The ED $50, E_{90}$ and ED $_{95}$ doses of pipecuronium and vecuronium under balanced and enflurane anaesthesia

\begin{tabular}{|c|c|c|c|c|}
\hline \multirow[b]{3}{*}{$n$} & \multicolumn{2}{|c|}{ Balanced anaesthesia } & \multicolumn{2}{|c|}{ Enflurane anaesthesia } \\
\hline & Pipecuronium* & Vecuronium $t$ & Pipecuronium* & Vecuroniumt \\
\hline & 28 & 18 & 29 & 15 \\
\hline $\mathrm{ED}_{50}$ & $20.3 \pm 1.1 \ddagger$ & 30.1 & $13.3 \pm 0.7$ & 21.5 \\
\hline $\mathrm{ED}_{50}$ & $33.0 \pm 1.6$ & 43.7 & $22.1 \pm 1.0$ & 26.7 \\
\hline $\mathrm{ED}_{50}$ & $35.1 \pm 1.7$ & 45.8 & $23.6 \pm 1.1$ & 27.4 \\
\hline
\end{tabular}

- Determined with cumulative dose method. 
TABLE III Neuromuscular effects under

\begin{tabular}{lllll}
\hline \multirow{4}{*}{ Variables } & \multicolumn{2}{l}{} & \\
\cline { 2 - 5 } & Palanced anaesthesia & & $\begin{array}{l}\text { Enflurane } \\
\text { Vecuronium (15) }\end{array}$ \\
\hline Intubating dose $\left(\mathrm{mg} \cdot \mathrm{kg}^{-1}\right)$ & 0.08 & 0.10 & 0.10 & 0.08 \\
Intubation time (min) & $1.8 \pm 0.1^{*}$ & $2.2 \pm 0.3$ & $2.6 \pm 0.2$ & $2.8 \pm 0.3$ \\
Onset time (min) & $3.6 \pm 0.4$ & $3.7 \pm 0.5$ & $5.9 \pm 1.0$ & $4.8 \pm 0.3$ \\
Maximal block (\%) & $99.3 \pm 0.3$ & $97.8 \pm 1.1$ & $>100$ & $>100$ \\
Clinical duration (min) & $110.5 \pm 0.3(19)$ & $115.8 \pm 8.1$ & $36.3 \pm 2.1 \dagger$ & $41.4 \pm 2.9$ \\
Recovery index (min) & $44.5 \pm 8.2(3)$ & $41.3 \pm 4.2(4)$ & $14.3 \pm 1.4 \dagger(9)$ & $21.0 \pm 3.1$ \\
\hline
\end{tabular}

*Mean \pm SEM of number of observations indicated in parenthesis.

$\dagger$ The clinical duration and recovery index of vecuronium was shorter $(P<0.001)$ than those of pipecuronium or pancuronium.

TABLE IV Clinical duration of maintenance doses

\begin{tabular}{llllll}
\hline \multirow{2}{*}{$\begin{array}{l}\text { Type of } \\
\text { anaesthesia }\end{array}$} & Compound & $\begin{array}{l}\text { Maintenance } \\
\text { dose }\left(\mu \mathrm{g} \cdot \mathrm{kg}^{-1}\right)\end{array}$ & First & Second & Third \\
\cline { 5 - 6 } \cline { 4 - 6 } Balanced & Pipecuronium & 15 & $51.5 \pm 5.4(29)$ & $57.0 \pm 5.3(17)$ & $57.7 \pm 16.6(3)$ \\
& Vecuronium & 15 & $13.8 \pm 0.8+(42)$ & $15.0 \pm 0.9 \dagger(36)$ & $15.9 \pm 1.2+(32)$ \\
& Pancuronium & 15 & $52.2 \pm 9.2(5)$ & - & - \\
Enflurane & Pipecuronium & 12 & $58.1 \pm 4.2(18)$ & $50.2 \pm 6.3(5)$ & $66.8 \pm 20.6(2)$ \\
& Vecuronium & 12 & $16.9 \pm 2.2 \dagger(12)$ & $17.7 \pm 1.7 \dagger(11)$ & $18.2 \pm 1+(9)$ \\
\hline
\end{tabular}

*Mean $\pm S E M$ of number of observations in parenthesis.

$\dagger$ Significantly different $(P<0.001)$ from pipecuronium and pancuronium

TABLE $\vee$ Reversal of the residual neuromuscular block under balanced anaesthesia

\begin{tabular}{|c|c|c|c|c|c|c|}
\hline & \multicolumn{2}{|c|}{ Pipecuronium (44) } & \multicolumn{2}{|c|}{ Pancuronium (23) } & \multicolumn{2}{|c|}{ Vecuronium $(I I)$} \\
\hline & $T$, & $T_{4} / T_{I}$ & $T_{I}$ & $T_{4} / T_{I}$ & $T_{1}$ & $T_{d} / T_{1}$ \\
\hline $\begin{array}{l}\text { Before reversal } \\
\text { After reversal } \dagger\end{array}$ & $37.3 \pm 3.3 *$ & $0.18 \pm 0.03$ & $49.5 \pm 5.8$ & $0.33 \pm 0.04$ & $77.2 \pm 7.4$ & $0.33 \pm 0.04$ \\
\hline $2 \min$ & $58.2 \pm 3.8$ & $0.47 \pm 0.04$ & $76.8 \pm 5.5$ & $0.78 \pm 0.03$ & $99.7 \pm 3.4$ & $0.86 \pm 0.03$ \\
\hline $5 \mathrm{~min}$ & $78.1 \pm 3.6$ & $0.67 \pm 0.03$ & $83.1 \pm 4.6$ & $0.79 \pm 0.03$ & $102.1 \pm 3.0$ & $0.90 \pm 0.02$ \\
\hline $8 \mathrm{~min}$ & $88.0 \pm 3.3$ & $0.75 \pm 0.02$ & $84.5 \pm 4.4$ & $0.80 \pm 0.03$ & - & - \\
\hline $10 \mathrm{~min}$ & $92.0 \pm 3.1$ & $0.79 \pm 0.02$ & - & - & - & - \\
\hline
\end{tabular}

*Mean \pm SEM of number of observations indicated in parenthesis.

†Pipecuronium-induced block was reversed with neostigmine, and both pancuronium- and vecuronium-induced blocks were reversed with edrophonium.

had no significant effect on these variables. The intubating dose of pancuronium increased heart rate by about 20 per cent $(P<0.01)$ and caused a moderate, not significant increase of systolic blood pressure.

\section{Discussion}

The neuromuscular potency of pipecuronium was found to be greater than that of vecuronium under both balanced and enflurane anaesthesia. Under balanced anaesthesia the neuromuscular potencies of both pipecuronium and vecuronium were greater than that of pancuronium determined by Donlon et al. ${ }^{6}$ earlier. The time course of the neuromuscular effects of pipecuronium were found to be similar to those of pancuronium. In agreement with this, except for the greater steady state distribution volume (VDss) and plasma clearance ( $\mathrm{Cl}$ ) the pharmacokinetic variables of pipecuronium and pancuronium were reported to be similar.?

Pipecuronium and vecuronium, unlike pancuronium, caused no elevation of the heart rate or blood pressure. 
TABLE VI Reversal of the residual neuromuscular block under enflurane anaesthesia

\begin{tabular}{clllll}
\hline & \multicolumn{2}{l}{ Pipecuronium (27) } & & \multicolumn{2}{l}{ Vecuronium (17) } \\
\cline { 2 - 3 } & $T_{I}$ & $T_{4} / T_{I}$ & & $T_{I}$ & $T_{4} / T_{I}$ \\
\hline Before reversal & $35.0 \pm 2.1^{*}$ & $0.22 \pm 0.03$ & & $76.7 \pm 5.1$ & $0.40 \pm 0.04$ \\
After reversal $\dagger$ & & & & \\
$2 \mathrm{~min}$ & $54.9 \pm 2.6$ & $0.63 \pm 0.02$ & & $101.0 \pm 3.1$ & $0.86 \pm 0.03$ \\
$5 \mathrm{~min}$ & $66.9 \pm 2.7$ & $0.80 \pm 0.02$ & & $104.2 \pm 2.3$ & $0.91 \pm 0.01$ \\
$8 \mathrm{~min}$ & $72.2 \pm 2.7$ & $0.85 \pm 0.01$ & & - \\
$10 \mathrm{~min}$ & $73.8 \pm 2.6$ & $0.88 \pm 0.01$ & & - \\
\hline
\end{tabular}

*Mean \pm SEM of number of observations indicated in parenthesis

$\dagger$ Pipecuronium and vecuronium induced blocks were reversed with neostigmine and edrophonium, respectively

TABLE VII Circulatory effects of the intubating dose of muscle relaxants under balanced anaesthesia

\begin{tabular}{llll}
\hline & $\begin{array}{l}\text { Pipecuronium(22) } \\
\left(0.08 \mathrm{mg} \cdot \mathrm{kg}^{-1}\right)\end{array}$ & $\begin{array}{l}\text { Pancuronium (10) } \\
\left(0.10 \mathrm{mg} \cdot \mathrm{kg}^{-1}\right)\end{array}$ & $\begin{array}{l}\text { Vecuronium(15) } \\
\left(0.10 \mathrm{mg} \cdot \mathrm{kg}^{-1}\right)\end{array}$ \\
\hline $\begin{array}{l}\text { Heart rate } \\
\text { Before injection of MR }\end{array}$ & $\begin{array}{l}76.2 \pm 3.8^{*} \\
\text { Before intubation }\end{array}$ & $\begin{array}{l}74.2 \pm 4.0 \\
92.7 \pm 5.4^{\dagger}\end{array}$ & $74.7 \pm 3.0$ \\
$\begin{array}{l}\text { Systolic blood pressure } \\
\begin{array}{l}\text { Before injection of MR } \\
\text { Before intubation }\end{array}\end{array}$ & $115.0 \pm 4.5$ & & $76.9 \pm 2.8$ \\
& $108.7 \pm 4.4$ & $129.4 \pm 5.4$ & $119.4 \pm 4.2$ \\
$\begin{array}{l}\text { Diastolic blood pressure } \\
\text { Before injection of MR }\end{array}$ & $69.0 \pm 3.2$ & $144.6 \pm 13.7$ & $114.1 \pm 3.1$ \\
Before intubation & $66.3 \pm 2.9$ & & $70.9 \pm 2.0$ \\
\hline
\end{tabular}

*Mean \pm SEM of number of observations indicated in parenthesis.

†Significantly $(P<0.05)$ different from preinjection values.

The difference in the cardiovascular effects of pipecuronium and vecuronium on one hand, and those of pancuronium on the other hand, may be explained by differences observed in their effect on the evoked release of norepinephrine from the isolated right atrium of the guinea-pig and on the force of contraction of the electrically stimulated atria. Pancuronium, because of its inhibitory effect on muscarinic receptors located on the noradrenergic nerve terminals and the pacemaker cells of the right atria increases the evoked release of norepinephrine and the force of contraction of the electrically stimulated right atria. ${ }^{8}$ These effects of pancuronium cause acceleration of heart rate and elevation of blood pressure. Pipecuronium ${ }^{9}$ and vecuronium ${ }^{8}$ have little or no inhibitory effect on these muscarinic receptors and consequently cause no elevation of heart rate and blood pressure.

It is of interest that in the group of patients in whom the dose-response of pipecuronium was determined under enflurane anaesthesia, after antagonism of the residual neuromuscular block, the $T_{4} / T_{1}$ ratio returned towards control more rapidly than $T_{1}$ (Table VI). The probable explanation of this finding is that enflurane inhibits contractility of the muscle fibre ${ }^{10}$ and this effect is not antagonized by neostigmine. In contrast in the vecuronium-enflurane group after antagonism of the residual neuromuscular block $T_{1}$ returned towards its control value more rapidly than the $T_{4} / T_{1}$ ratio. The probable explanation of this apparent discrepancy is that the effect of enflurane on contractility of the muscle develops and wears off slowly ${ }^{10}$ and the mean \pm SEM duration of exposure to enflurane was $170.2 \pm 19.1 \mathrm{~min}$ in the pipecuronium and $87.4 \pm 8.8 \mathrm{~min}$ in the vecuronium group.

Pipecuronium appears to be a suitable replacement for pancuronium for the production of muscular relaxation of relatively long duration in patients in whom elevation of heart rate has to be avoided.

\section{References}

1 Alant $O$, Darvas K, Pulay I, Weliner J, Bihari I. First clinical experience with a new neuromuscular blocker, Pipecuronium bromide. Arzneimittel Forschung 1980; 30: 374-9.

2 Bunjatjian A, Miheev $V$. Clinical experience with a new 
stcroid muscle relaxant: pipecuronium bromide.

Arzneimittel Forschung 1980; 30: 383-5.

3 Boros M, Szenoszradsky J, Marosi G, Toth I. Comparative clinical study of pipecuronium bromide and pancuronium bromide. Arzneimittel Forschung 1980; 30: 389-93.

4 Tassonyi $E$, Szabo $G$, Vimlati $L$. Pipecuronium bromide (Arduan). In: Kharkevich DA (Ed.). Handbook of Experimental Pharmacology. Berlin: Springer Verlag, 1986; 590-616.

5 Weiner BJ. Statistical Principles of Experimental Design. New York, San Francisco, Toronto, London: McGrawHill, 1962; 83-104.

6 Donlon JV, Savarese JJ, Ali HH, Teplik RS. Human dose-response curves for neuromuscular blocking drugs: a comparison of two methods of construction and analysis. Anesthesiology 1980; 53: 161-6.

7 Caldwell JE, Castagnoli KP, Canfell PC et al. Pipecuronium and pancuronium: comparison of pharmacokinetics and duration of action. Br J Anaesth 1988; 61: 693-7.

8 Foldes $F F$, Kobayashi $O$, Kinjo $M$ et al. Presynaptic effect of muscle relaxants on the release of ${ }^{3} \mathrm{H}$-norepinephrinc controlled by endogenous acetylcholine in guinea pig atrium. Neural Transm 1988; 76: 169-80.

9 Vizi ES, Kobayashi $O$, Tôroćsik $O$ et al. Heterogeneity of presynaptic muscarinic receptors involved in modulation of transmitter release. Neuroscience $1989 ; 31$ : $259-$ 67.

10 Foldes FF, Nagashima H, Ohta Yet al. Modification of the neuromuscular blocking effect of vecuronium by various anesthetic agents. In: Agoston S, Bowman WC, Miller RD, Viby-Mogensen J (Eds.). Clinical Experiences with Norcuron. Amstcrdam: Excerpta Medica, 1983; 132-9. 